\title{
Dietary patterns of the elderly: characteristics and association with socioeconomic aspects
}

\section{Abstract}

Objective: To investigate the association between dietary patterns and the socioeconomic aspects of elderly patients registered with the Family Health Strategy in Viçosa, Minas Gerais. Method: A cross-sectional study with a probabilistic sample was employed. To identify dietary patterns, dietary intake was assessed through a Food Frequency Questionnaire (FFQ) adapted for an elderly population. From the FFQ dietary patterns were identified by factor analysis. After the identification of the dietary patterns, logistic regression was performed considering each different dietary pattern and the related socioeconomic variables. Results: The consumption of a Fat and sugar pattern was greater among women and lower in elderly persons who considered themselves as mixed race. The consumption of the Balanced pattern was also lower among mixed race, married individuals, with one to four years of schooling and from the CDE economic classes. The Fruit and fish pattern was less consumed by elderly persons with 1-4 years of schooling, while the opposite was observed among those with five years or more of study. But the consumption of a Leafy vegetables pattern was lower among those with five or more years of schooling. Conclusion: The evaluation of the consumption of dietary patterns and the establishment of a relationship with the socioeconomic aspects of the elderly helps to achieve a better understanding of risk and protective factors for health.

\footnotetext{
Universidade Federal de Goiás (UFG), Faculdade de Medicina, Departamento de Pós-graduação em Ciências da Saúde. Goiânia, Goiás, Brasil.

2 Universidade Federal do Oeste da Bahia (UFOB), Centro de Ciências Biológicas e da Saúde, Departamento de Nutrição. Barreiras, Bahia, Brasil.

3 Faculdade Atenas, Unidade Paracatu, Departamento de Nutrição. Paracatu, Minas Gerais, Brasil.

4 Faculdade de Ciências e Tecnologia de Viçosa (FACISA/UNIVIÇOSA), Departamento de Fisioterapia. Viçosa, Minas Gerais, Brasil.

5 Universidade Federal de Viçosa (UFV), Departamento de Nutrição. Viçosa, Minas Gerais, Brasil.
}

\author{
Jacqueline Danesio Souza ${ }^{\top}$ \\ Marcos Vidal Martins² \\ Fernanda Silva Franco ${ }^{3}$ \\ Karina Oliveira Martinho4 \\ Adelson Luiz Tinôco ${ }^{5}$
}

\section{Keywords: Food}

Consumption. Health of

the Elderly. Socioeconomic Factors. 


\section{INTRODUCTION}

Understanding the implications and consequences of the growth of the elderly population in Brazil is a major challenge for public health ${ }^{1,2}$. The health profile of this population group is characterized by the replacement of acute or fatal illnesses with an increase in the number of individuals affected by chronic noncommunicable diseases (CND) and their complications, which have a direct relationship with dietary intake ${ }^{3-7}$. A better understanding of the reality of the diet of the elderly is possible through the development and use of dietary patterns that establish different relationships between nutrition and health processes ${ }^{8-10}$.

Evaluating the dietary patterns of the elderly and their association with the social and economic environment in which they are inserted is important to establish a better representation of the reality of the Brazilian elderly with regard to food and health determinants ${ }^{5,11,12}$. Therefore, the present study aimed to investigate the association between dietary patterns and the socioeconomic aspects of the elderly population registered with the Family Health Strategy (FHS) in the municipality of Viçosa, Minas Gerais.

\section{METHOD}

An epidemiological cross-sectional study with a random sample was performed of elderly persons of both genders receiving care at all the FHS units in Viçosa, Minas Gerais, from August 2011 to June 2012. The sample size calculation considered a confidence level of $95 \%$, a $65 \%$ prevalence of metabolic syndrome and a variability of $5 \%$. The sample therefore contained 331 elderly persons, to which was added $20 \%$ to cover potential losses, giving a total of 398 elderly persons. The final sample comprised 402 elderly individuals.

The data was collected through visits to units of the FHS, where a structured and standardized questionnaire, which had been pre-tested in a pilot study, was applied. The socioeconomic and self-reported and demographic variables analyzed were gender, age, skin color/ethnicity, marital status, education (years of study) and economic class. Economic class was assessed and categorized according to the Critério de Classificação Econômica da Associação Brasileira de Empresas de Pesquisa (the Economic Classification Criteria of the Brazilian Association of Research Companies) ${ }^{13}$.

To assess food patterns, the Food Frequency Questionnaire (FFQ), a qualitative tool validated for the elderly, was used ${ }^{14}$. This includes a list of foods containing 93 items and the frequency of intake (daily, weekly, monthly, rarely or never). In order to minimize errors in the study, the name of each food on the FFQ and its frequency was read aloud, and it was emphasized that consumption over the previous year was being discussed. No feelings or opinions regarding the responses of the elderly about the consumption of certain foods were expressed.

From the FFQ variables, the dietary patterns of the population were identified. The validity of the construction of food patterns was investigated by exploratory factor analysis to test the relationship between the different foods. The Kaiser-Meyer-Olkin (KMO) coefficient was calculated and Bartlett's sphericity test was applied to assess the applicability and appropriateness of correlations between the variables.

Principal component analysis of the FFQ was carried out, followed by an orthogonal rotation (varimax) to examine the exploratory factor structure, improving the interpretation of the data. The number of factors was defined as the variance graph of the number of components (screen plot), where the steepest points indicate the appropriate number of components to be retained. Foods with a consumption equal to or less than $25 \%$ were excluded from the FFQ. Foods that contributed to the characterization of each pattern exhibited factorial loads with values equal to or greater than 0.2, as per Schulze et al. ${ }^{15}$. From this analysis, we identified four patterns of consumption, namely Fat and sugar, Balanced, Fruit and fish and Leafy vegetables. The names of the patterns were created to represent the main components found.

After the extraction of each food pattern, four logistic regressions were performed, considering in each a different food pattern as the dependent variable and the socioeconomic variables as the independent variables. These models were adjusted considering $\mathrm{p}<0.05$.

The study fully complied with the guidelines for research involving human beings, in accordance with Resolution n0 196/96 of the National Health Council. 
The elderly persons participated voluntarily and signed a Free and Informed Consent Form. The present study was approved by the Ethics Research Committee of the Universidade Federal de Viçosa (the Federal University of Viçosa) (record no 039/2011).

\section{RESULTS}

A total of 402 elderly persons participated in the study, the majority of whom were female (60.56\%), brown-skinned/mixed race $(48.76 \%)$ and married $(56.72 \%)$. Most had an educational level between one and four years (58.21\%) and were classified as being of the lowest economic class, CDE (89.3\%) (Table 1).

In Table 2 shows the distribution of the factor loads of the food consumption patterns, extracted from the food present in the FFQ of the elderly persons, as well as the type of food that was part of each pattern and its factor load.
The final multiple logistic regression model for each dietary pattern, according to the socioeconomic variables, is described in Table 3. It was noted that women were $14 \%$ more likely to have a dietary pattern of Fat and sugar. With regard to ethnicity/skin color, it is noted that describing oneself as brown-skinned/mixed race reduced the probability of consuming this dietary pattern.

The consumption of a Balanced diet was lower in brown-skinned/mixed race individuals. The same relationship was observed among married elderly persons, with one to four years of schooling and from CDE economic class.

The consumption of the Fruit and fish pattern was lower among elderly persons with one to four years of schooling, with the opposite being observed in those with five or more years of study. But the Leafy Vegetables pattern of consumption was lower among those with five or more years of education.

Table 1. Characterization of sample based on socioeconomic and demographic variables. Viçosa, Minas Gerais, 2012.

\begin{tabular}{lll}
\hline Variable & Categories & $\mathrm{n}(\%)$ \\
\hline Gender & Male & $159(39.55)$ \\
& Female & $243(\mathbf{6 0 . 4 5})$ \\
Skin color/ethnicity & White/Caucasian & $109(27.11)$ \\
& Brown/Mixed Race & $196(\mathbf{4 8 . 7 6})$ \\
& Black/Afro-Brazilian & $97(24.13)$ \\
\hline Marital Status & Single & $28(6.97)$ \\
& Married & $228(\mathbf{5 6 . 7 2})$ \\
& Divorced/separated & $19(4.73)$ \\
\hline Economic class & Widowed & $127(31.59)$ \\
\hline Level of education & AB & $43(10.7)$ \\
& CDE & $359(\mathbf{8 9 . 3})$ \\
\hline
\end{tabular}

Table 2. Distribution of factor loads of food consumption patterns of elderly persons. Viçosa, Minas Gerais, 2012.

\begin{tabular}{lllll}
\hline \multirow{2}{*}{ Foods } & \multicolumn{4}{c}{ Food patterns } \\
\cline { 2 - 5 } & Fat and sugar & Balanced & Fruit and fish & Leafy vegetables \\
\hline French fries & 0.2341 & - & & - \\
\hline Yucca fries & 0.2557 & - & - & - \\
\hline Pork & 0.2431 & - & - & - \\
\hline
\end{tabular}


continued from table 2

\begin{tabular}{|c|c|c|c|c|}
\hline Sausage & 0.2242 & - & - & - \\
\hline Crackling & 0.2335 & - & - & - \\
\hline Sugar & 0.2639 & - & - & - \\
\hline Soda & 0.2338 & - & - & - \\
\hline Biscuit and salt Water & - & 0.2158 & - & - \\
\hline Chicory & - & 0.2014 & - & - \\
\hline Pumpkin & - & 0.2640 & - & - \\
\hline Chayote & - & 0.2317 & - & - \\
\hline Orange & - & 0.2909 & - & - \\
\hline Banana & - & 0.2165 & - & - \\
\hline Apple & - & 0.2685 & - & - \\
\hline Boiled beef & - & 0.2105 & - & - \\
\hline Ground beef & - & 0.2167 & - & - \\
\hline Broccoli & - & - & 0.2514 & - \\
\hline Watermelon & - & - & 0.2772 & - \\
\hline Papaya & - & - & 0.2026 & - \\
\hline Pear & - & - & 0.3227 & - \\
\hline Cauliflower & - & - & 0.2203 & - \\
\hline Fish & - & - & 0.2130 & - \\
\hline Cabbage & - & - & - & 0.2316 \\
\hline Milkweed & - & - & - & 0.3436 \\
\hline Mustard & - & - & - & 0.3660 \\
\hline
\end{tabular}

Table 3. Analysis of multiple logistic regression for each dietary pattern, according to socioeconomic variables. Viçosa, Minas Gerais, 2012.

\begin{tabular}{|c|c|c|c|c|c|c|c|c|}
\hline \multirow{3}{*}{ Variables } & \multicolumn{8}{|c|}{ Dietary pattern } \\
\hline & \multicolumn{2}{|c|}{ Fat and sugar } & \multicolumn{2}{|c|}{ Balanced } & \multicolumn{2}{|c|}{ Fruit and fish } & \multicolumn{2}{|c|}{ Leafy vegetables } \\
\hline & $\overline{\mathrm{OR}}$ & $p$ & OR & $p$ & OR & $p$ & OR & $p$ \\
\hline \multicolumn{9}{|l|}{ Gender } \\
\hline Male & 1.0 & & --- & & --- & & & \\
\hline Female & 1.14 & 0.001 & & & & & & \\
\hline \multicolumn{9}{|l|}{ Skin color } \\
\hline White/Caucasian & 1.0 & & 1.0 & & --- & & --- & \\
\hline Brown/Mixed race & 0.82 & 0.001 & 0.53 & 0.04 & & & & \\
\hline Black/Afro-Brazilian & 0.36 & 0.23 & 0.24 & 0.42 & & & & \\
\hline \multicolumn{9}{|l|}{ Marital status } \\
\hline Single & --- & & 1.0 & & & & & \\
\hline Married & & & 0.93 & 0.02 & & & & \\
\hline Divorced/separated & & & 0.52 & 0.39 & & & & \\
\hline Widowed & & & 0.66 & 0.13 & & & & \\
\hline \multicolumn{9}{|l|}{ Level of education } \\
\hline Illiterate & --- & & 1.0 & & 1.0 & & 1.0 & \\
\hline 1 to 4 years & & & -1.08 & 0.001 & 0.49 & 0.01 & 0.29 & 0.12 \\
\hline
\end{tabular}


continued from table 3

\begin{tabular}{|c|c|c|c|c|c|c|c|}
\hline 5 years or more & & 0.20 & 0.41 & 1.62 & 0.001 & -0.59 & 0.02 \\
\hline \multicolumn{8}{|l|}{ Economic class } \\
\hline $\mathrm{AB}$ & --- & 1.0 & & 1.0 & & --- & \\
\hline CDE & & 0.99 & 0.001 & -1.06 & 0.001 & & \\
\hline
\end{tabular}

OR: odds ratio.

\section{DISCUSSION}

It is observed that food intake among the elderly is mainly influenced by physiological factors related to appetite reduction, deglutition disorders, and decreased gustatory and olfactory ability, which all contribute to the decreased absorption of vitamins, minerals and other nutrients, causing the depletion of nutritional status and health ${ }^{5,16,17}$.

The factorial analysis extracted from the FFQ was performed to identify dietary patterns which represent the food intake patterns of the population of the study. Such a methodology has been used in many studies ${ }^{10,12,18}$. Of the four patterns identified, the first, entitled Fat and sugar was considered harmful to health as it consisted of foods high in fat and sugar. The second pattern was composed of carbohydrate-rich foods, fruits, vegetables and meats, and was entitled Balanced; the third had lots of fruit and was also composed of fish, being referred to as Fish and fruit; and the fourth was comprised of leafy vegetables and tea, and was known as Leafy Vegetables.

The Fat and sugar dietary pattern was more common in females, while being brown-skinned/ mixed race reduced the probability of the consumption of this dietary pattern. Different studies report that the food consumption of the elderly is marked by a high intake of foods that are rich in fat and sugars and low in the consumption of fruits and vegetables ${ }^{19,23}$. Data from Vigitel revealed the consumption of fruit and vegetables in Brazil is below $400 \mathrm{~g} /$ day, the amount recommended by the World Health Organization (WHO ${ }^{24}$.

The reduced consumption of foods that are a source of vitamins and minerals or the adoption of a monotonous diet by elderly can lead to a depletion in the intake of nutrients that are essential for maintaining health and controlling disease ${ }^{7,25,26}$. It is noteworthy that the process of nutritional transition is marked by the excessive consumption of sugars, fats, soft drinks, and the insufficient consumption of fruits, vegetables and fiber, which contributes to the occurrence of unfavorable consumption patterns ${ }^{5,20}$.

Maintaining a balanced food intake with the presence of foods such as fruits, vegetables and the low intake of fried foods and fats minimizes the development of cardiovascular diseases among the elderly ${ }^{27,28}$. Among the nutritional strategies to improve nutrition and health are the control of cardiovascular risk factors that accompany lifestyle change, as different dietary patterns modulate various aspects of atherosclerosis and cardiovascular risk factors, such as plasma lipid levels, systemic insulin resistance and glucose metabolism, blood pressure, oxidative phenomena, endothelial function and vascular inflammation ${ }^{27}$.

Increased consumption of food sources of saturated fats and sugars is directly associated with a higher prevalence of cardiovascular diseases and obesity $^{29}$, and it has been found that cardiovascular disease is $40 \%$ more prevalent in areas with lower socioeconomic levels. Similar findings of inadequate intake and overweight were observed in a study by Nascimento et $\mathrm{al}^{30}$. When considering these factors as indicators of inadequate dietary habits, studies relating to household surveys have found a heightened growth of overweight and obesity, especially in social strata of lower income $e^{20,28,31}$.

The Fruit and fish pattern of food consumption was lower in elderly persons with one to four years of study, a finding which was not observed among those with five or more years of study. Recent national data has revealed that elderly Brazilians have an inadequate diet, with a high prevalence of insufficient intake of vitamins $\mathrm{A}, \mathrm{C}, \mathrm{D}, \mathrm{E}$, thiamine and pyridoxine, and the minerals calcium, magnesium, zinc and copper, 
as well as the habitual consumption of excessive sodium31. Proper nutrition, with a high consumption of fruit and fish, brings health benefits, reducing the prevalence of $\mathrm{NCDs}^{32}$.

It should be noted that the present study was based on non-institutionalized, low-income elderly persons. Other studies have shown that this population has a lower calorie diet than those with a high income. It is known that income is a key factor in diet quality, as, because of insufficient economic resources, elderly persons have an inferior dietary pattern than those with greater purchasing power ${ }^{3,33,34}$.

The comparison between dietary patterns and socioeconomic aspects in the present study is limited compared to other scientific studies, as works that consider these factors are scarce. The absence of a gold standard to assess food intake, especially among the elderly, is a major limiting factor. In addition, the cross-sectional design of the study makes it impossible to establish a cause-and-effect relationship between the measures assessed.

\section{CONCLUSION}

The findings of this study indicate that the Fat and sugar pattern of food consumption was more prevalent among women and less prevalent among those who considered themselves brown-skinned/ mixed race. The Balanced pattern of consumption was also lower among brown-skinned/mixed race individuals, as well as those who were married, with one to four years of schooling, and those from the CDE economic class. The Fruit and Fish pattern was consumed less by elderly persons with an education level of from one to four years of schooling, while the opposite was observed among those with five or more years of study. The Leafy Vegetables pattern of consumption, however, was lower among those with five or more years of education.

It is important to emphasize the need for constant monitoring of dietary patterns and the encouraging of healthy eating practices. Such actions can mitigate the effects of poor diet on general health and the incidence of morbidities among the elderly. Studies correlating the dietary patterns and socioeconomic aspects of the elderly should also be encouraged, as the results show strong correlations with risk and protective factors for health. They also provide greater knowledge of the subject and broaden the discussion about the different factors associated with the food consumption of the elderly.

\section{REFERENCES}

1. Instituto Brasileiro de Geografia e Estatística. Dados preliminares do censo 2010 [Internet]. Rio de Janeiro: IBGE; 2010 [acesso em 20 Jan. 2013]. Disponível em: http://www.ibge.gov.br

2. Silva VL, Leal MCC, Marino JG, Marques APO. Associação entre carência social e causas de morte entre idosos residentes no Município de Recife, Pernambuco, Brasil. Cad Saúde Pública. 2008;24(5):1013-23.

3. Stival MM, Lima LR, Karnikowski MGO. Relações hipotéticas entre os determinantes sociais da saúde que influenciam na obesidade em idosos. Rev Bras Geriatr Gerontol. 2015;18(2):433-42.
4. Martinho KO, Dantas EHM, Longo GZ, Ribeiro AQ, Pereira ET, Franco FS, et al. Comparison of functional autonomy with associated sociodemographic factors, lifestyle, chronic diseases (CD) and neuropsychiatric factors in elderly patients with or without the metabolic syndrome (MS). Arch Gerontol Geriatr. 2013;57(2):151-5.

5. Assumpção D, Domene SMA, Fisberg RM, Barros MBA. Qualidade da dieta e fatores associados entre idosos: estudo de base populacional em Campinas, São Paulo, Brasil. Cad Saúde Pública. 2014;30(8):1680-94.

6. Martins MV, Ribeiro AQ, Martinho KO, Franco FS, Souza JD, Morais KBD, et al. Anthropometric indicators of obesity as predictors of cardiovascular risk in the elderly. Nutr Hosp. 2015;31(6);2583-9. 
7. Leenders M, Sluijs I, Ros MM, Boshuizen HC, Siersema PD, Ferrari P, et al. Fruit and vegetable consumption and mortality: european prospective investigation into cancer e nutrition. Am J Epidemiol. 2013;178(4):590-602.

8. Moreira PRS, Rocha NP, Milagres LC, Novaes JF. Análise crítica da qualidade da dieta da população brasileira segundo o Índice de Alimentação Saudável: uma revisão sistemática. Ciênc Saúde Coletiva. 2015;20(12):3907-23.

9. D'Innocenzo S, Marchioni DML, Prado MS, Matos SMA, Pereira SRS, Barros AP, et al. Condições socioeconômicas e padrões alimentares de crianças de 4 a 11 anos: estudo SCAALA - Salvador/Bahia. Rev Bras Saúde Mater Infant. 2011;11(1):41-9.

10. Olinto MTA. Padrões Alimentares: análise de componentes principais. In: Kac G, Sichiery R, Gigante DP, organizadores. Epidemiologia nutricional. Rio de Janeiro: Fiocruz; 2007. p. 213-25.

11. Alizadeh M, Mohtadinia J, Pourghasem-Gargari B, Esmaillzadeh A. Major dietary patterns among female adolescent girls of Talaat Intellingent Guidance School, Tabriz, Iran. Iran Red Crescent Med J. 2012;14(7):436-41.

12. HoffmannI JF, Nunes MAA, Schmidt MI, Olinto MTA, Melere C, Ozcariz SGI, et al. Dietary patterns during pregnancy and the association with sociodemographic characteristics among women attending general practices in southern Brazil: the ECCAGe Study. Cad Saúde Pública. 2013;29(5):970-80.

13. Associação Brasileira de Empresas de Pesquisas. Critério de Classificação Econômica Brasil [Internet]. São Paulo; 2008 [acesso em 12 Set. 2013]. Disponível em: www.abep.org/codigosguias/CCEB2008Base2006e2007.pdf

14. Abreu WCD. Aspectos socioeconômicos, de saúde e nutrição, com ênfase no consumo alimentar de idosos atendidos pelo Programa Municipal da Terceira Idade (PMTI), de Viçosa - MG [tese]. Viçosa: Universidade Federal de Viçosa; 2003.

15. Schulze MB, Hoffmann K, Kroke A, Boeing H. An approach to construct simplified measures of dietary patterns from exploratory factor analysis. Br J Nutr. 2003;89(3):409-18.

16. Abreu WC, Franceschini SCC, Tinoco ALA, Pereira CAS, Silva MMS. Inadequação no consumo alimentar e fatores interferentes na ingestão energética de idosos matriculados no Programa Municipal da Terceira Idade de Viçosa (MG). Rev Baiana Saúde Pública. 2008;32(2):190-202.
17. Inzitari M, Doets E, Bartali B, Benetou V, Di Bari M, Visser M, et al. Nutrition in the agerelated disablement process. J Nutr Health Aging. 2011;15(5):599-604.

18. Perozzo G, Olinto MTA, Dias-da-Costa JS, Henn RL, Sarriera J, Pattussi MP. Associação dos padrões alimentares com obesidade geral e abdominal em mulheres residentes no Sul do Brasil. Cad Saúde Pública. 2008;24(10):2427-39.

19. Freitas AMDP, Philippi ST, Ribeiro SML. Listas de alimentos relacionadas ao consumo alimentar de um grupo de idosos: análises e perspectivas. Rev Bras Epidemiol. 2011;14(1):161-77.

20. Silveira EA, Martins BB, Abreu LRS, Cardoso CKS. Baixo consumo de frutas, verduras e legumes: fatores associados em idosos em capital no Centro-Oeste do Brasil. Ciênc Saúde Coletiva. 2015;20(12):3689-99.

21. Park SY, Ollberding NJ, Woolcott CG, Wilkens LR, Henderson BE, Kolonel LN. Fruit and vegetable intakes are associated with lower risk of bladder cancer among women in the multiethnic Cohort Study. J Nutr. 2013;143(8):1283-92.

22. Venturini CD, Engroff P, Sgnaolin V, El Kik RM, Morrone FB, Da Silva Filho IG, et al. Consumo de nutrientes em idosos residentes em Porto Alegre (RS), Brasil: um estudo de base populacional. Ciênc Saúde Coletiva. 2015;20(12):3701-11.

23. Hiza HAB, Casavale KO, Guenther PM, Davis CA. Diet quality of Americans differs by age, sex, race/ ethnicity, income, and education level. J Acad Nutr Diet. 2012;113(2):297-306.

24. Iser BPM, Yokota RTC, Sá NNB, Moura L, Malta DC. Prevalência de fatores de risco e proteção para doenças crônicas nas capitais do Brasil: principais resultados do Vigitel 2010. Ciênc Saúde Coletiva. 2012; 17(9):2343-56.

25. Brasil. Ministério da Saúde, Departamento de Análise de Situação de Saúde, Secretaria de Vigilância em Saúde. Plano de ações estratégicas para o enfrentamento das doenças crônicas não transmissíveis (DCNT) no Brasil 2011-2022. Brasília, DF: Ministério da Saúde; 2011.

26. Malta MB, Papini SJ, Corrente JE. Avaliação da alimentação de idosos de município paulista: aplicação do Índice de Alimentação Saudável. Ciênc Saúde Coletiva. 2013;18(2):377-84

27. Santos RD, Gagliardi ACM, Xavier HT, Magnoni CD, Cassani R, Lottenberg AMP, et al. Primeira Diretriz sobre o consumo de Gorduras e Saúde Cardiovascular. Arq Bras Cardiol. 2013;100(1 Supl.3):1-40. 
28. Freitas AMDP, Philippi ST, Ribeiro SML. Listas de alimentos relacionadas ao consumo alimentar de um grupo de idosos: análises e perspectivas. Rev Bras Epidemiol. 2011;14(1):161-77.

29. Godoy MF, Lucena JM, Miquelin AR, Paiva FF, Oliveira DLQ, Augustin Junior JL, et al. Mortalidade por Doenças Cardiovasculares e Níveis Socioeconômicos na População de São José do Rio Preto, Estado de São Paulo, Brasil. Arq Bras Cardiol. 2007;88(2):200-6.

30. Nascimento CM, Ribeiro AQ, Cotta RMM, Acurcio FA, Peixoto SV, Priore SE, et al. Estado nutricional e fatores associados em idosos do Município de Viçosa, Minas Gerais, Brasil. Cad Saúde Pública. 2011;27(12):2409-18.

Received: February 24, 2016

Reviewed: August 22, 2016

Accepted: October 7, 2016
31. Fisberg RM, Marchioni DML, Castro MA, Verly Junior E, Araújo MC, Bezerra IN, et al. Ingestão inadequada de nutrientes na população de idosos do Brasil: Inquérito Nacional de Alimentação 2008-2009. Rev Saúde Pública. 2013;47(1 Supl):222-30.

32. Rique ABR, Soares EA, Meirelles CM. Nutrição e exercício na prevenção e controle das doenças cardiovasculares. Rev Bras Med Esporte. 2002;8(6):244-54.

33. Guthrie JF, Lin BH. Overview of the diets of lowerand higher-income elderly and their food assistance options. J Nutr Educ Behav. 2002;34(1):31-41.

34. Campos MTFS, Monteiro JBR, Ornelas APRC. Fatores que afetam o consumo alimentar e a nutrição do idoso. Rev Nutr. 2000;13(3):157-65. 